\title{
Analisis Kausalitas Pertumbuhan Ekonomi terhadap Indeks Pembangunan Manusia
}

\author{
Muslikhati \\ Program Studi Ekonomi Syariah, \\ Fakultas Agama Islam, Universitas Muhammadiyah Malang \\ E-mail: muslikhati@umm.ac.id
}

\begin{abstract}
Human development is one of the indicators of the success of economic growth. The good quality of human resources goes hand in hand with economic growth, this is because resources as part of the factor of production are the most valuable assets in the economic activities of a country. This study aims to determine and analyze the causality of economic growth towards the quality of human resources. The method used in this study was using the Granger Causality method. Granger Causality Approach is used to measure the strength of the relationship between two or more variables, or it can also be used as a tool to see the direction of the relationship between independent variables and the dependent variable. The variable Human Development Index (HDI) as the dependent variable and per capita income variable as the independent variable. From this study it was concluded that the granger causality test on the proposed research model states that there is no causality relationship between two independent variables and the dependent variable, but significantly the Indonesian economic growth variable has a oneway relationship with the human development index (HDI).
\end{abstract}

Keywords: Economic Growth, Human Development Index. 


\begin{abstract}
ABSTRAK
Pembangunan manusia adalah salah satu indikator keberhasilan pertumbuhan ekonomi. Kualitas sumber daya manusia yang baik sejalan dengan pertumbuhan ekonomi, ini karena sumber daya sebagai bagian dari faktor produksi adalah aset yang paling berharga dalam kegiatan ekonomi suatu negara. Penelitian ini bertujuan untuk mengetahui dan menganalisis kausalitas pertumbuhan ekonomi terhadap kualitas sumber daya manusia. Metode yang digunakan dalam penelitian ini menggunakan metode granger causality. Pendekatan ini digunakan untuk mengukur kekuatan hubungan antara dua variabel atau lebih, atau bisa juga digunakan sebagai alat untuk melihat arah hubungan antara variabel independen dan variabel dependen. Variabel Indeks Pembangunan Manusia (IPM) sebagai variabel dependen dan variabel pendapatan perkapita sebagai variabel independen. Dari penelitian ini disimpulkan bahwa uji kausalitas granger pada model penelitian yang diusulkan menyatakan bahwa tidak ada hubungan kausalitas antara dua variabel independen dan variabel dependen, tetapi secara signifikan variabel pertumbuhan ekonomi Indonesia memiliki hubungan satu arah dengan indeks pembangunan manusia. (HDI).
\end{abstract}

Kata Kunci: Pertumbuhan Ekonomi, Pembangunan Manusia.

\title{
1. Pendahuluan
}

Pembangunan manusia adalah salah satu dari indikator keberhasilan pertumbuhan ekonomi. Baiknya kualitas sumber daya manusia berjalan searah dengan pertumbuhan ekonomi, hal ini dikarenakan sumber daya sebagai bagian dari faktor produksi merupakan aset yang paling berharga dalam aktivitas ekonomi sebuah negara. Disamping itu pertumbuhan ekonomi yang tinggi juga akan dapat dicapai jika, sumber daya yang dimiliki oleh negara mampu berkompetisi dalam skala global. Kompetisi ini dapat diwujudkan melalui kualitas yang handal (Kuncoro, 2009)

Kualitas sumber daya manusia yang dimiliki oleh setiap negara sangat tergantung pada ketersediaan sarana dan prasarana penunjang. Sarana yang baik seperti, ketersediaan pelayanan pendidikan, kesehatan dan infrasturktur lainnya, akan dapat memacu peningkatan sumber daya yang baik. Begitu pula dengan ketersediaan prasarana yang menunjang. Fasilitas yang baik didapatkan dari pendapatan negara yang juga baik. Sayangnya, tidak semua negara didunia dapat memenuhi kebutuhan masyarakatnya. Karena tidak semua negara memiliki tingkat pendapatan yang tinggi. Salah satu unsur yang dapat mendorong pertumbuhan ekonomi adalah tingginya tingkat pendapatan perkapita. Pendapatan perkapita juga merupakan salah satu indikator kemajuan dan kesejahteraan sebuah negara. Klasifikasi negara menurut maju, berkembang dan miskin salah satunya juga dengan indikator angka pendapatan negara tersebut. 
PDB Indonesia terus meningkat, dari $\$ 857$ pada tahun 2000 menjadi $\$ 3.603$ pada 2016. Dengan nilai pendapatan yang meningkat pada tahun 2016, saat ini Indonesia adalah negara dengan jumlah penduduk terbesar keempat di dunia, dengan ekonomi terbesar kesepuluh berdasarkan paritas daya beli, dan merupakan anggota G-20. Meningkatnya nilai pendapatan negara Indonesia telah berhasil mengurangi kemiskinan lebih dari setengahnya sejak tahun 1999, menjadi 10,9\% pada tahun 2016.

Čadila, Petkovová, \& Blatná (2014) menyatakan bahwa pertumbuhan ekonomi yang tinggi tidak secara langsung berpengaruh terhadap kualitas sumber daya manusia atau human capital, sebaliknya, tingginya kualitas sumber daya manusia juga tidak selalu dapat meningkatkan kualitas sumber daya manusia suatu negara, terkadang justru tingginya kualitas sumber daya manusia atau human capital meningkatkan angka pengangguran. Hal ini dapat terjadi karena kualitas yang tinggi mendorong manusia untuk mencari lapangan pekerjaan yang sesuai dengan kemampuan dan pendapatan yang diharapkan, sementara ketersediaan lapangan pekerjaan dan upah yang ditawarkan di pasar tenaga kerja dibawah expectation dari pencari kerja. Para pencari kerja ini akhirnya rela menunda untuk mendapatkan pekerjaan karena mencari jenis pekerjaan yang lebih layak dengan upah yang lebih tinggi.

Melliana \& Zain (2013) melakukan penelitian terhadap faktor-faktor yang berpengaruh terhadap peningkatan indeks kualitas sumber daya manusia dengan penemuan yakni faktor pendorong peningkatan kualitas sumber daya manusia adalah pembangunan yang terencana seperti anggaran untuk pendidikan, dengan peningkatan angka partisipasi sekolah.

\section{Kajian Pustaka}

\subsection{Teori Pertumbuhan Ekonomi}

Menurut Adam Smith perekonomian akan tumbuh dan berkembang jika tambahnya jumlah penduduk atau populasi penduduk mendorong peningkatan spesialisasi yang akan berpengaruh terhadap produktivtas tenaga kerja dan perkembangan teknologi. Faktor-faktor inilah yang akan meningkatkan pertumbuhan ekonomi. David Ricardo berpendapat bahwa tiap pertumbuhan penduduk berakibat pada melimpahnya tenaga kerja. Dengan banyaknya tenaga kerja menyebabkan upah yang diterima oleh pekerja menurun. Menurunnya upah pekerja ini hanya dapat digunakan untuk memenuhi kebutuhan hidup yang sifatnya primer (basic need), pada kondisi seperti ini perekonomian mengalami masa stagnan atau disebut sebagai stationary state. Teori Pertumbuhan versi Malthus mengemukakan tentang pertambahan makanan yang sesuai dengan deret hitung, sementara bertambahnya manusia sesuai dengan deret ukur. Dampak dari teori ini adalah, pada suatu masa, dengan bertambahnya penduduk yang semakin banyak, cadangan makanan akan semakin berkurang. Pada kondisi ini akan terjadi kondisi dimana permintaan atau demand akan lebih besar dari penawaran bahan makanan. Dengan kondisi shortage, akan terjadi kemandegan ekonomi. 
Harrod-Domar menyatakan bahwa dalam mewujudkan pertumbuhan ekonomi yang tinggi diperlukan pembentukan modal (investasi), dengan investasi yang tinggi perekonomiaan akan kuat (steady growth). Investasi akan meningkatkan produktivitas barang dan jasa. Tentunya dengan produktvitas yang tinggi akan mendorong pertumbuhan ekonomi yang tinggi pula. Pertumbuhan ekonomi menurut Schumpeter ditentukan oleh kemampuan perdagangan (enterpreneur). Kemampuan ini mendorong sebuah negara berinovasi dalam aktivitas produksi. Solow berpendapat, modal dalam jangka panjang ditentukan oleh tabungan atau saving. Semakin banyak masyarakat yang menabung, akan semakin tinggi ketersediaan modal jangka panjang yang berimbas pada kemampuan produksi nasional. Menurut Kuznets, teori pertumbuhan adalah pertumbuhan dengan kemampuan suatu negara dalam jangka panjang dalam menyediakan berbagai jenis barang konsumsi denga jumlah yang sangat banyak. Lebih jelasnya Kuznets mengemukakan bahwa pertumbuhan ekonomi dicapai oleh 3 faktor yaitu: pertama, peningkatan persediaan barang yang terus-menerus. kedua, perkembangan teknologi. ketiga, penggunaan teknologi secara efektif dan efisien.

\subsection{Human Capital}

Kasper \& Streit (2012) menjelaskan bahwa di dalam proses pertumbuhan ekonomi ada beberapa faktor yang harus diperhatikan antara lain K (Capital), L (Labour), Tec (Technology), dan SK (Skill). Mulanya faktor skill dan pendidikan masih belum mendapat perhatian lebih karena fokus perhatian masih mengarah pada tersedianya sumber daya alam yang melimpah sebagai penunjang pertumbuhan ekonomi, namun setelah tahun 1960-an hasil studi dan hasil penelitian mulai memperhatikan faktor penting sebagai penunjang pertumbuhan ekonomi selain dukungan sumber daya alam yaitu faktor pendidikan dan skill.

Human capital menjadi sebuah piranti yang mempengaruhi bagaimana perekonomian di suatu negara tumbuh dan berkembang. Pendidikan dan skill dapat membantu peningkatan Capital Stock sehingga mampu mendorong peningkatan produktivitas modal yang dimiliki. Ketika komponen pendidikan dan skill ini terakomodasi dengan sempurna, maka akan mampu meningkatkan perekonomian dengan lebih efisien disamping variabel tenaga kerja dan modal Kasper (2012).

\subsection{Indeks Pembangunan Manusia}

Indeks pembangunan manusia menjelaskan bagaimana penduduk dapat mengakses hasil pembangunan dalam memperoleh pendapatan, kesehatan, pendidikan, dan sebagainya. Indeks ini diperkenalkan oleh United Nations Development Programme (UNDP) pada tahun 1990 dan dipublikasikan secara berkala dalam laporan tahunan Human Development Report (HDR). Indeks ini dibentuk oleh 3 (tiga) dimensi dasar, yaitu: umur panjang dan hidup sehat, pengetahuan dan standar hidup layak. 
Manfaat Indeks Pembangunan Manusia adalah, (1) merupakan indikator penting untuk mengukur keberhasilan dalam upaya membangun kualitas hidup manusia (masyarakat/penduduk), (2) menentukan peringkat atau level pembangunan suatu wilayah atau negara. (3) untuk Negara Indonesia, Indeks ini merupakan data strategis karena selain sebagai ukuran kinerja Pemerintah, juga digunakan sebagai salah satu alokator penentuan Dana Alokasi Umum (DAU)

\subsection{Penelitian Terdahulu}

Qureshi (2009) penelitian yang berjudul human development, public expenditure and economic growth: a system dynamics approach mencoba menelaah tentang pengeluaran pemerintah atau belanja publik terhadap peningkatan pertumbuhan ekonomi dan peningkatan kualitas sumber daya manusia. Menggunakan metode sistem dinamis didapatkan hasil bahwa belanja pemerintah (belanja publik) yang rendah tidak akan dapat meningkatkan kualitas sumber daya manusia. Ogundare \& Awokuse (2018), melakukan penelitian terhadap pengaruh variabel sumber daya manusia terhadap pertumbuhan ekonomi, dimana instrumen indeks pembangunan manusia menggunakan dua pengukuran yakni pendidikan dan kesehatan. Dari penelitian ini diketahui bahwa kualitas pembangunan manusia berkontribusi positif terhadap pertumbuhan ekonomi dengan sumbangsih instrumen kesehatan lebih besar daripada instrumen pendidikan.

Arora, Rashmi, Jalilian, \& Hossen (2018), dalam financial development, human capital and economic growth at the subnational level: the Indian case ini menguji tentang interaksi antara pengembangan keuangan, modal manusia dan pertumbuhan ekonomi di tingkat sub-nasional menggunakan data panel yang mencakup 23 negara bagian India untuk periode 1999-2013. Dari hasil analisis didapatkan bahwa ada bukti hubungan positif antara modal manusia dan pengembangan keuangan terhadap pertumbuhan ekonomi. Hasil penelitian yang sama juga di peroleh dari riset yang dilakukan oleh (Ulas \& Keskin, 2017).

Čadila et al., (2014) dalam human capital, economic structure and growth menyatakan bahwa tingginya nilai IPM tidak serta merta meningkatkan laju perekonomian. Tingginya kualitas manusia atau yang disebut sebagai modal manusia, biasanya dipandang sebagai salah satu penentu utama daya saing dan pertumbuhan ekonomi. Namun, dari hasil riset ditemukan bahwa sumber daya manusia tidak menjadi jaminan stabilitas ekonomi. Ini dibuktikan pada riset yang dilakukan di negara Spanyol, dimana tingkat modal manusia, yang dinyatakan sebagai persentase dari populasi berpendidikan tinggi, relatif sangat tinggi tetapi pengangguran mencapai tingkat kritis dan pertumbuhan ekonomi lemah atau negatif. Simpulan dari penelitian ini adalah sumber daya manusia harus mencerminkan struktur ekonomi untuk mendorong pertumbuhan ekonomi. Jika 
tidak, maka tingginya indeks pembangnan manusia yang tersermin dalam modal manusia hanya akan menyebabkan tingkat pengangguran yang lebih tinggi karena efek crowding out dan ketidakseimbangan di pasar tenaga kerja.

Selanjutnya penelitian yang berbeda di lakukan oleh Aydin (2017) yang lebih mendefinisikan kualitas sumber daya manusia berdasarkan pada pengukuran yang berbeda antara pengukuran secara konvensional dengan pengukuran yang dilakukan dalam perpektif Islam dengan judul risetnya islamic vs conventional human development index: empirical evidence from ten Muslim countries menyatakan bahwa Peringkat ${ }^{\mathrm{i}} \mathrm{HDI}$ untuk semua negara Muslim berbeda dari yang ada di ${ }^{c}$ HDI. Perbedaannya ini berdasarkan pada perkembangan ekonomi pada masing-masing negara. Dengan demikian, tingginya kualitas sumber daya manusia dengan pengukuran secara konvensional tidak berarti bahwa mereka bergerak menuju pembangunan manusia yang ideal. Temuan ini menegaskan perlunya pendekatan pengindeksan pembangunan manusia alternatif dari perspektif Islam.

\section{Metode Penelitian}

Penelitian ini diharapkan mampu menganalisa tentang kausalitas atau hubungan antara variabel independen terhadap variabel dependennya dan atau variabel dependen terhadap variabel independennya. Dengan tujuan penelitian tersebut, maka penelitian ini merupakan penelitian kuantitatif dengan analisis Kausalitas Granger. Pendekatan kausalitas granger digunakan untuk mengukur kekuatan hubungan antara dua variabel atau lebih, atau dapat pula digunakan sebagai alat untuk melihat arah hubungan antara variabel bebas dengan variabel terikatnya. Sehingga penelitian ini melihat dari sisi sebab-akibatnya (Kuncoro, 2009).

\section{Hasil dan Pembahasan}

Berdasarkan tabel pengujian granger causality, hasil pengujian kausalitas pada lag 3 diperoleh bahwa nilai sig. sebesar 0,0682 untuk Pertumbuhan Ekonomi Indonesia terhadap Indeks Pembangunan Manusia (IPM/HDI), kemudian nilai sig. sebesar 0,1531 untuk Indeks Pembangunan Manusia terhadap Pertumbuhan Ekonomi Indonesia. Berlandaskan pada nilai alpha penelitian $(\alpha)=10 \%$, hal ini dapat disimpulkan bahwa nilai sig 0,0682 < 0,1 untuk variabel Net Export terhadap Gross Domestic Product menolak Ho, yang dapat diartikan bahwa Pertumbuhan Ekonomi Indonesia berpengaruh terhadap Indeks Pembangunan Manusia (IPM/HDI). gujian Hipotesis 
Tabel 1.1

Granger Causality Test

\begin{tabular}{|c|c|c|c|}
\hline \multicolumn{4}{|l|}{$\begin{array}{l}\text { Pairwise Granger Causality Tests } \\
\text { Date: 05/12/18 Time: 08:02 } \\
\text { Sample: } 20052015 \\
\text { Lags: } 3\end{array}$} \\
\hline Null Hypothesis: & Obs & F-Statistic & Prob. \\
\hline PEI1 does not Granger Cause IPM & 8 & 115.577 & 0.0682 \\
\hline IPM does not Granger Cause PEI1 & & 22.6173 & 0.1531 \\
\hline
\end{tabular}

Sumber: Data diolah, 2018

Uji granger causality juga menunjukkan bahwa nilai sig untuk variabel Indeks Pembangunan Manusia (IPM/HDI) terhadap Pertumbuhan Ekonomi Indonesia sebesar 0,1531 >0,1. Hal ini dapat disimpulkan bahwa Ho diterima, yang diartikan sebagai Pembangunan Manusia (IPM/HDI) tidak mempengaruhi kenaikan atau penurunan Pertumbuhan Ekonomi Indonesia. Dengan demikian terjadi hubungan satu arah antara Pertumbuhan Ekonomi Indonesia terhadap Indeks Pembangunan Manusia (IPM/HDI) untuk Negara Indonesia.

4.1. Kausalitas Pertumbuhan Ekonomi Indonesia terhadap Indeks Pembangunan Manusia (IPM/HDI):

Hasil analisis dari uji granger causality terhadap model penelitian yang diajukan menyatakan bahwa tidak ada hubungan kausalitas antara dua variabel independen dan variabel dependen, namun demikian secara signifikan variabel Pertumbuhan Ekonomi (PE) Indonesia mempunyai hubungan satu arah dengan indeks pembangunan manusia (IPM). Artinya bahwa, pertumbuhan ekonomi yang tinggi mempengaruhi peningkatan kualitas sumber daya manusia, akan tetapi tinggi nya kualitas sumber daya manusia tidak secara otomatis mempengaruhi pertumbuhan ekonomi.

Pengaruh pertumbuhan ekonomi yang signifikan terhadap peningkatan kualitas sumber daya manusia sesuai dengan penelitian yang dilakukan oleh Pradnya (Pradnyadewi \& Purbadharmaja, 2017). Hasil temuan dalam penelitian ini menyatakan bahwa, pertumbuhan ekonomi (PE) berpengaruh signifikan terhadap tingginya nilai kualitas sumber daya manusia atau IPM. Nilai IPM yang tinggi merupakan sumbangsih dari pertumbuhan ekonomi yang tinggi dengan melihat sumbangsih pengeluaran pemerintah yang terdiri dari belanja pendidikan dan kesehatan.

Secara teori pertumbuhan ekonomi memiliki pengaruh signifikan terhadap kualitas sumber daya manusia. Peningkatan ini, seperti dalam penelitian Pradnya, merupakan sumbangsih dari belanja pemerintah atas faktor-faktor yang 
mempengaruhi peningkatan kualitas manusia. Temuan ini juga didukung oleh riset yang dilakukan oleh Lonni, yang menyatakan bahwa, tingginya perekonomian suatu bangsa yang dapat dilihat dari nilai pertumbuhan ekonominya dapat meningkatkan kualitas sumber daya manusianya. Sumber peningkatan kualitas tersebut diperoleh dari belanja untuk kesehatan, belanja pendidikan, dan fasilitas-fasilitas lain penunjang peningkatan kualitas sumber daya manusia.(Lonni, Kasnawi, \& Uppun, 2018).

Jika melihat data pertumbuhan ekonomi Indonesia sejak tahun 2010, maka akan terlihat bahwa pertumbuhan ekonomi Indonesia cenderung mengalami penurunan yang diawali sejak tahun 2011, pertumbuhan ekonomi Indonesia berada pada kisaran angka 4\% hingga 6\% pertahun. (BPS:, 2018). Pertumbuhan ekonomi Indonesia mengalami penurunan sejak tahun 2010 dan mengalami kenaikan pada tahun 2016 dan 2017. Berikut data pertumbuhan ekonomi negara Indonesia menurut Badan Pusat Statistik atau BPS.

\section{Grafik 1.1}

Pertumbuhan Ekonomi Indonesia 2010 - 2017

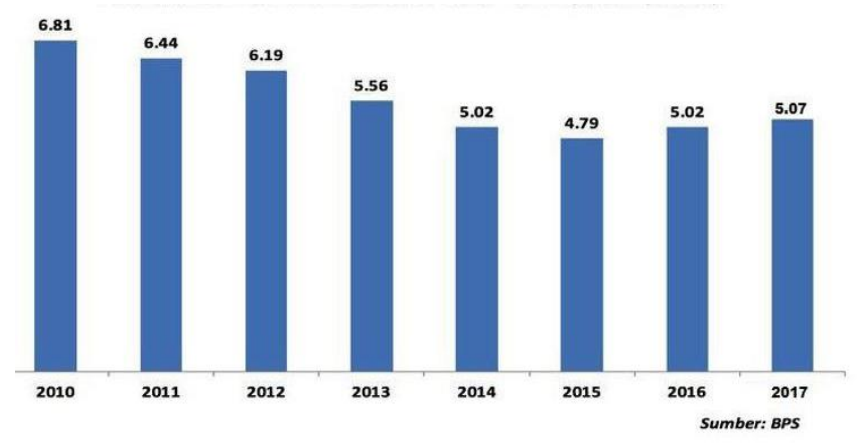

Pertumbuhan ekonomi yang tinggi terutama pada tahun 2010 dan tahun 2017 merupakan sumbangsih dari beberapa sektor ekonomi yang hingga kini masih merupakan sektor unggulan dari 17 sektor penyumbang PDB (Pendapatan Domestik Bruto), sektor-sektor tersebut adalah sektor pertanian, manufaktur, dan Pariwisata (Bappenas, 2017). Jika merujuk pada angka pertumbuhan ekonomi pada data diatas, maka sesuai dengan teori dan temuan yang dilakukan oleh Pradnya dan Lonni, maka pada tahun yang sama kualitas sumber daya manusia di negara Indonesia seharusnya juga memiliki nilai dan capaian yang sama dengan angka pertumbuhannya. Akan tetapi jika dilihat dari data berikut, nilai kualitas sumber daya manusia terus mengalami peningkatan kualitas dari tahun ke tahun. 
Jika dilihat dari data Indeks Pembangunan Manusia (IPM) Tabel 1.1, dapat disimpulkan bahwa pertumbuhan ekonomi tidak berpengaruh terhadap peningkatan kualitas sumber daya manusia. Ini dapat diketahui dari data pertumbuhan ekonomi Indonesia selama kurun waktu 2010 yang terus mengalami penurunan dan baru meningkat pada tahun 2016 dan 2017. Sementara dari data kualitas sumber daya manusia, sejak tahun 2010 terus mengalami peningkatan hingga tahun 2017. Capaian kualitas sumber daya manusia didapatkan dari kontribusi belanja negara yang mendorong peningkatan kualitas sumber daya manusia sesuai dengan pos-posnya.

Tabel 1.2

Indeks Pembangunan Manusia Indonesia

\begin{tabular}{|c|c|c|c|c|c|c|c|}
\hline $\mathbf{2 0 1 0}$ & $\mathbf{2 0 1 1}$ & $\mathbf{2 0 1 2}$ & $\mathbf{2 0 1 3}$ & $\mathbf{2 0 1 4}$ & $\mathbf{2 0 1 5}$ & $\mathbf{2 0 1 6}$ & $\mathbf{2 0 1 7}$ \\
\hline 66,53 & 67,09 & 67,7 & 68,31 & 68,9 & 69,55 & 70,18 & 70,81 \\
\hline
\end{tabular}

Sumber: Badan Pusat Statistik, 2017

Dari grafik diatas dapat kita ketahui bahwa pergerakan pertumbuhan ekonomi tidak sejalan dengan pergerakan kualitas sumber daya manusianya. Hal ini bisa diakibatkan alokasi belanja pemerintah dengan pertumbuhan tinggi tidak dialokasikan secara maksimal untuk meningkatkan kualitas SDMnya. Temuan ini tidak sejalan dengan penelitian yang dilakukan oleh Arora yang menyatakan bahwa ada bukti hubungan positif antara modal manusia terhadap pertumbuhan ekonomi. (Arora et al., 2018) Arora dalam penelitiannya menyatakan bahwa sumber daya manusia dapat mempengaruhi pertumbuhan ekonomi melalui saluran inovasi dan seiring dengan perkembangan keuangan dapat menjadi pelengkap atau pengganti dalam hubungannya dengan pertumbuhan ekonomi. Ini menguatkan hasil penelitian yang mengemukakan tentang hubungan signifikan antara pertumbuhan ekonomi dengan variabel indek pembangunan manusia dan indeks pembangunan manusia dengan pertumbuhan ekonomi.

Temuan ini juga sejalan dengan penelitian (Ogundare \& Awokuse, 2018) yang menyatakan bahwa, kontribusi IPM terhadap pertumbuhan ekonomi tidak dapat berjalan sendiri, artinya tingginya kualitas sumber daya manusia tidak secara langsung akan mempengaruhi tingginya pertumbuhan ekonomi sebuah negara, jika tidak diikuti dengan upaya nyata yang mengarah pada perilaku untuk meningkatkan nilai mutu SDM. Penelitian yang dilakukan di Afrika ini memuat kesimpulan bahwa, Indeks IPM yang tinggi yang didukung oleh faktor-faktor peningkatan kualitas pendidikan dan kesehatan mampu berkontribusi terhadap peningkatan pertumbuhan ekonomi. Meskipun dari kedua faktor ini angka kesehatan yang dapat dilihat dari angka harapan hidup memiliki kontribusi yang lebih tinggi dibandingkan dengan faktor pendidikan yang terlihat dari rata-rata 
lama sekolah dan harapan lama sekolah (ekpektasi untuk lulus tepat waktu). Dari penelitian ini dapat disimpulkan bahwa tingginya angka pertumbuhan ekonomi sebuah negara tidak secara langsung meningkatkan kualitas manusianya, akan tetapi tergantung pada seberapa besar dukungan dan kontribusi pemerintah untuk meningkatkan kualitas sumber dayanya.

\section{Grafik 1.2 \\ Perbandingan Nilai Indeks Pembangunan Manusia dan Pertumbuhan Ekonomi}

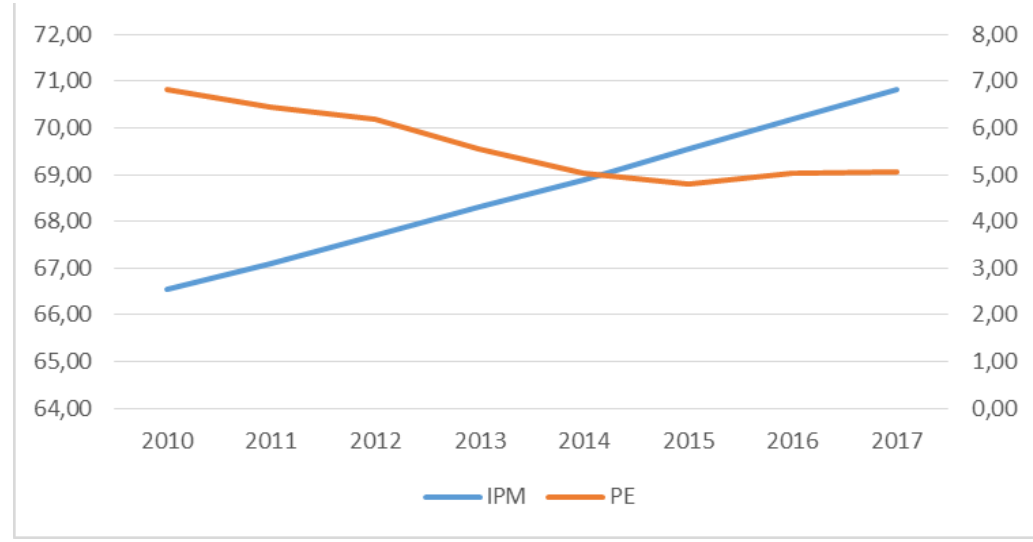

Sumber: Data Diolah, 2018

Hasil yang sama juga didapat dari penelitian Sehrawat dan Giri (2014), penelitian yang berjudul The relationship between financial development indicators and human development in India menyatakan bahwa indikator pengembangan keuangan bertindak sebagai pendorong penting untuk peningkatan modal manusia di India. Hasil ini menunjukkan bahwa, kausalitas berjalan dari indikator keuangan yang terdiri dari kredit dan sektor swasta ke sumber daya manusia. Indikator keuangan terkait erat dengan pertumbuhan ekonomi dan pembangunan manusia di India. Analisis dekomposisi varians menunjukkan bahwa di antara semua indikator keuangan, jumlah uang beredar luas (M2) telah memberikan kontribusi terbesar terhadap perubahan dalam sumber daya manusia. Temuan ini dengan jelas menekankan bahwa tinggi rendahnya kualitas sumber daya manusia di sebuah negara tidak bergantung pada tinggi rendahnya pertumbuhan ekonomi, akan tetapi sangat dipengaruhi oleh seberapa besar kontribusi sektor-sektor penunjang kualitas sumber daya manusia.

Jika dalam kajian teori disebutkan bahwa pertumbuhan ekonomi yang tinggi akan berpengaruh terhadap nilai manusia atau kualitas SDM, sehingga dari teori ini kemudian masing-masing negara berupaya dengan berbagai cara untuk meningkatkan perolehan PDBnya untuk menaikkan mutu SDMnya. Upaya ini 
bisa dilakukan dengan membuat indikator pengukuran pertumbuhan ekonomi yang hanya memasukkan unsur-unsur yang sifatnya terukur tanpa melibatkan unsur-unsur yang bersifat tidak terukur yang ada pada setiap negara. Indikator pertumbuhan yang terkadang juga masih menimbulkan polemik dan perbedaan pendapat, pertentangan di setiap negara karena memiliki perspektif yang sangat luas yang sangat memungkinkan untuk memasukkan banyak indikator didalamnya. Melengkapi kepingan Puzzle hubungan antara pertumbuhan ekonomi dan kualitas sumber daya manusia yang masih terkoyak karena banyaknya persepsi dan indikator capaiannya maka Aydin (2017) kemudian mendefinisikan kualitas sumber daya manusia berdasarkan pada pengukuran yang berbeda antara pengukuran secara konvensional dengan pengukuran yang dilakukan dalam perpektif Islam dengan judul risetnya Islamic $v s$ conventional Human Development Index: empirical evidence from ten Muslim countries. Dari Penelitian ini didapatkan hasil bahwa Peringkat ${ }^{i}$ HDI untuk semua negara Muslim berbeda dari yang ada di ${ }^{c} \mathrm{HDI}$ atau pengukuran indek kualitas SDM di negara yang menggunakan pengukuran secara konvensional. Perbedaannya ini berdasarkan pada perkembangan ekonomi pada masing-masing negara. Dengan demikian, dinyatakan bahwa tingginya angka kualitas sumber daya manusia yang diukur dengan pengukuran konvensional akan memiliki hasil yang berbeda dengan pengukuran sistem Islam. Ini berarti bahwa tingginya angka pertumbuhan ekonomi di sebuah negara belum tentu dapat diartikan bahwa mereka bergerak menuju pembangunan manusia yang ideal. Temuan ini menegaskan perlunya pendekatan pengindeksan pembangunan manusia alternatif dari perspektif Islam.

\section{Kesimpulan}

Dari hasil uji granger causality menyatakan bahwa tidak ada hubungan kausalitas antara dua variabel independen (PE) dan variabel dependen (IPM), namun demikian secara signifikan variabel Pertumbuhan Ekonomi (PE) Indonesia mempunyai hubungan satu arah dengan indeks pembangunan manusia (IPM). Hasil penelitian ini memberikan analisis yang berbeda dari penelitian terdahulu dimana hubungan antar variabel dapat bersifat positif maupun negatif, artinya, pertumbuhan ekonomi bisa berpengaruh terhadap peningkatan kualitas sumber daya manusia, sementara kualitas sumber daya manusia tidak selalu berpengaruh terhadap tingginya nilai pertumbuhan ekonomi. Indikator yang baru untuk mengukur hubungan ekonomi yang tinggi dengan kualitas SDM perlu dilakukan dengan menggunakan indikator yang berbeda. Indikator yang memungkinkan bisa digunakan adalah indikator pengukuran ekonomi dengan kualitas SDM dengan indikator Islami. 


\section{Daftar Pustaka}

Arora, Rashmi, Jalilian, \& Hossen. (2018). Financial Development, Human capital and Economic Growth at the Subnational level: The Indian Case. Journal of Banking, Finance and Sustainable Development. University of Bradford.

Aydin, N. (2017). Islamic vs conventional Human Development Index: empirical evidence from ten Muslim countries. Emerald Group Publishing Limited.

Bappenas. (2017). 2018, pemerintah fokus kembangkan tiga sektor.

BPS: (2018). Peningkatan Kualitas SDM Tercermin dalam IPM.

Čadila, J., Petkovová, L., \& Blatná, D. (2014). Human Capital, Economic Structure and Growth. Elsevier.

Kasper, \& Streit. (2012). Human Capital.

Kuncoro, M. (2009). Ekonomika Indonesia. Jogja.

Lonni, Kasnawi, T., \& Uppun, P. (2018). Pengaruh Kualitas Sumber Daya Manusia terhadap ekonomi di kabupaten Mamasa. Http://Pasca.Unhas.Ac.Id/Jurnal/Files/4013e72702847521673251f61042c080. $P d f$.

Melliana, A., \& Zain, I. (2013). Analisis Statistika Faktor yang Mempengaruhi Indeks Pembangunan Manusia di Kabupaten/Kota Provinsi Jawa Timur dengan Menggunakan Regresi Panel. Jurnal Sains Dan Seni ITS, 2(2), D237-D242. Retrieved from http://ejurnal.its.ac.id/index.php/sains_seni/article/view/4844

Ogundare, K., \& Awokuse, T. (2018). Human capital contribution to economic growth in Sub-Saharan Africa: Does health status matter more than education? Elsevier, Economic Analysis and Policy, 58, 131-140.

Pradnyadewi, D., \& Purbadharmaja, I. B. (2017). Pengaruh IPM, biaya infrastruktur, investasi dan pertumbuhan ekonomi terhadap ketimpangan distribusi pendapatan di provinsi bali. E-Jurnal Ekonomi Pembangunan Universitas Udayana, 6, 255-285.

Qureshi, M. azeem. (2009). Human development, public expenditure and economic growth: a system dynamics approach. Emerald Group Publishing Limited.

Sehrawat, M., \& Giri, A. K. (2014). The relationship between financial development indicators and human development in India. Emeraldinsight, 41. https://doi.org/10.1108/IJSE-11-2013-0268

Ulas, E., \& Keskin, B. (2017). Is There a Relation Between HDI and Economic Performances? In New Trends in Finance and Accounting (p. 1). https://doi.org/10.1007/978-3-319-49559-0_6 